\title{
ASSESSMENT OF PROFITABILITY AND BREAK-EVEN POINTS IN SUCKLER COW HERDS
}

\author{
Jan Syrůček ${ }^{1}$ Luděk Bartoňํ, Jindřich Kvapilík, Mojmír Vacek², Luděk Stádník²

\begin{abstract}
${ }^{1}$ Department of Cattle Breeding, Institute of Animal Science, Přátelství 815, 10400 Prague 10 - Uhříněves, Czech Republic

${ }^{2}$ Department of Animal Husbandry, Faculty of Agrobiology, Food and Natural Resources, Czech University of Life Sciences Prague, Kamýcká 129, 16521 Prague 6 - Suchdol, Czech Republic
\end{abstract}

\begin{abstract}
SYRU゚ČEK JAN, BARTOŇ LUDĚK, KVAPILÍK JINDŘICH, VACEK MOJMÍR, STÁDNÍK LUDĚK. 2018. Assessment of Profitability and Break-Even Points in Suckler Cow Herds. Acta Universitatis Agriculturae et Silviculturae Mendelianae Brunensis, 66(3): 707-715.

Suckler cow enterprises comprise an important segment of Czech agriculture, and the number of suckler cows has been steadily increasing in recent years. The objective of this study was to assess the profitability of suckler cow herds in the Czech Republic based upon data collected for 2014, 2015, and 2016 using a questionnaire covering production, reproduction, and economic traits. The average yearly costs reached 30,583 CZK per cow. When subsidies in the average amount of 14,347 CZK per cow were included, profitability of $8.3,8.7$, and $6.3 \%$ was observed in 2014,2015 , and 2016, respectively. Feed, labour, depreciation, and overheads were the largest cost items and together comprised $66 \%$ of total yearly costs. The data obtained proved the economy of scale. Average breakeven points were determined for the number of weaned calves, calving interval, and selling price of calves ( 75 calves, 465 days, and $56 \mathrm{CZK} / \mathrm{kg}$ live weight, respectively). A sensitivity analysis identified the number of weaned calves, price of calves, calving interval, and amount of subsidies as the most influential parameters.
\end{abstract}

Keywords: break-even point, costs, economies of scale, profitability, sensitivity analysis, subsidies, suckler cows

\section{INTRODUCTION}

As in most other European Union (EU) countries, cattle production is one of the most important segments of livestock production in the Czech Republic (CR). As reported in the Economic Accounts for Agriculture, the contribution of cattle and milk to the total revenues from animal production at current prices amounts to $63 \%$ (Czech Statistical Office, 2017a). Suckler cows represent an important percentage of Czech cattle herds, comprising $37 \%$ of the total cow population in 2016 (Czech Statistical Office, 2017a). In 2016, there were in total 12.1 million suckler cows in EU-28 countries, and this number has not changed markedly in the last 10 years (Eurostat, 2017). In the CR, however, the suckler cow population has recently been increasing considerably despite declining bovine meat production and low per capita beef consumption. Over the past decade (2007 to 2017), suckler cow numbers have increased by 62,000 head $(40 \%)$, and the population as of 1 April 2017 was 216,095 head (Czech Statistical Office, 2017a).

Sustainability and future development of suckler cow herds are dependent upon, among other factors, achieving a reasonable level of profitability. Cow-calf production systems are influenced by a number of extrinsic and intrinsic factors that are reflected to various extents in their overall economic success. The effects of these factors are not isolated but interact with each other. It has been shown that a negative impact of a single such factor cannot necessarily be offset fully by above-average results achieved as measured by the others (Kvapilík et al., 2006). As reported 
in many studies, the production of weaned calves on permanent grasslands is the main objective of suckler cow operations; therefore, economically successful herd management is closely associated with fertility of the cows (e.g., Wolfová et al., 2005; Kvapilík and Zahrádková, 2007). It is reported that a prerequisite for herd profitability is to have average number of weaned calves per 100 cows in excess of 90 (Sacher and Diener, 2004; Kvapilík et al., 2006). Relatively low labour and investment costs are typical for this type of operation (Michaličková et al., 2016), and it is noteworthy that suckler cows play a role in providing employment opportunities in some less favoured areas (Boudný and Janotová, 2012).

Various payment supports are an important source of income for suckler cow operations. Most studies on the subject agree that suckler cow herds are unprofitable and unsustainable over the long term without subsidies (Wolfová et al., 2004; Jones, 2007). Subsidies are paid to farmers with the intention of meeting in part the costs ensuing from the non-productive functions provided by cattle herds and which are not adequately covered by the market sale of products (Kvapilík and Zahrádková, 2007). In addition to direct payments, beef cattle breeders farming in leass favoured areas are entitled to the payments that compensate for significantly higher production costs and prevent farmers from leaving the areas of natural restrictions (Lososová et al., 2016).
A number of other factors also influence the profitability of suckler cow herds, including breed (Davies et al., 2009), nutrition (Nayigihugu et al., 2007), herd replacement rate (Berger, 2014), price of weaned calves (Wolfová et al., 2004), and health problems (Taylor et al., 2012).

The objectives of this study were to evaluate the profitability of suckler cow herds in the CR during the period 2014-2016, assess the impact of subsidies, and determine the economic efficiency using break-even points and sensitivity analyses.

\section{MATERIALS AND METHODS}

\section{Data}

Input data were collected from cow-calf farms located in every regions of the CR. The data were obtained for 2014, 2015, and 2016 using a questionnaire containing 95 questions structured in seven parts: basic information, reproduction characteristics, weights and weight gains, herd turnover, revenue and subsidies, yearly costs, and farmers' views on various factors influencing the economic performance of their suckler cow herds. Totals of 20,22, and 19 farms of different size responded to the questionnaire in 2014, 2015, and 2016, respectively. Fifteen of these provided data in all three years. In 2014, 2015, and 2016, average data were obtained in relation to 2,527, 2,734, and 2,517 suckler cows, respectively. Different production

I: Basic indicators for suckler cow herds analysed.

\begin{tabular}{|c|c|c|c|c|}
\hline Item & Unit & $\begin{array}{c}2014 \\
\text { Mean } \pm \text { SD }\end{array}$ & $\begin{array}{c}2015 \\
\text { Mean } \pm \text { SD }\end{array}$ & $\begin{array}{c}2016 \\
\text { Mean } \pm \text { SD }\end{array}$ \\
\hline Average number of cows in herd & $\mathrm{n}$ & $126 \pm 92$ & $124 \pm 92$ & $132 \pm 97$ \\
\hline Number of cows per ha of permanent grassland & $\mathrm{n}$ & $0.3 \pm 0.1$ & $0.4 \pm 0.1$ & $0.5 \pm 0.2$ \\
\hline Number of cows per worker & $\mathrm{n}$ & $35 \pm 19$ & $40 \pm 16$ & $46 \pm 11$ \\
\hline Use of natural service & $\%$ & $87 \pm 13$ & $79 \pm 18$ & $80 \pm 8$ \\
\hline Age at first calving & days & $936 \pm 135$ & $924 \pm 134$ & $915 \pm 126$ \\
\hline Calving interval & days & $412 \pm 37$ & $401 \pm 27$ & $399 \pm 48$ \\
\hline Number of calves born per 100 cows and year & $\mathrm{n}$ & $89 \pm 11.3$ & $92 \pm 6.2$ & $93 \pm 9.4$ \\
\hline Twinning rate & $\%$ & $0.26 \pm 0.43$ & $0.77 \pm 2.25$ & $1.50 \pm 1.89$ \\
\hline Loss of calves & $\%$ & $5.5 \pm 5.1$ & $4.9 \pm 5.2$ & $2.4 \pm 0.7$ \\
\hline Number of calves weaned per 100 cows and year & $\mathrm{n}$ & $84 \pm 13.5$ & $87 \pm 7.1$ & $91 \pm 11.1$ \\
\hline Age of calves at weaning & months & $7.6 \pm 1.0$ & $8.3 \pm 1.2$ & $8.0 \pm 1.1$ \\
\hline Herd turnover rate & $\%$ & $15.1 \pm 5.2$ & $13.5 \pm 5.2$ & $13.2 \pm 5.5$ \\
\hline Birth weight of calves - bulls & $\mathrm{kg}$ & $42 \pm 3$ & $42 \pm 3$ & $41 \pm 4$ \\
\hline Birth weight of calves - heifers & $\mathrm{kg}$ & $36 \pm 3$ & $38 \pm 4$ & $37 \pm 3$ \\
\hline Live weight of calves at age 120 days - bulls & $\mathrm{kg}$ & $179 \pm 14$ & $190 \pm 26$ & $184 \pm 22$ \\
\hline Live weight of calves at age 120 days - heifers & $\mathrm{kg}$ & $150 \pm 21$ & $167 \pm 31$ & $170 \pm 13$ \\
\hline Live weight of calves at age 210 days - bulls & $\mathrm{kg}$ & $294 \pm 15$ & $311 \pm 37$ & $304 \pm 27$ \\
\hline Live weight of calves at age 210 days - heifers & $\mathrm{kg}$ & $234 \pm 28$ & $267 \pm 43$ & $268 \pm 30$ \\
\hline
\end{tabular}

$\mathrm{SD}=$ standard deviation. 
and reproduction traits were observed and their average values in respective years are given in Tab. I. In addition, also recorded were various cost items, revenues, and support payments received. Clear outlying values were excluded from further analyses.

\section{Methods}

Herd revenues included those from calf sales and support payments. The income realized on calf sales was based on the live weight of a calf sold and the selling price per kilogram of calf live weight. Support for suckler cows at the time of data analysis included mainly the following payments (Ministry of Agriculture, 2017):

- Single area payment scheme (SAPS) and greening - direct payments;

- Voluntary coupled support (VCS) targeted to specific sectors - beef calves (earlier specific support under Article 68 of Council Regulation (EC) No 73/2009);

- Transitional national subsidies (PVP) - for agricultural land and beef cattle;

- Payments for less favoured areas; and

- Payments from rural development programmes relating to agri-environment, climate, and organic farming.

In 2015 and 2016, due to changes in the EU Common Agricultural Policy, the payment for greening was added whereas the SAPS rate per hectare was reduced (SAPS rates were 5,997, 3,544 , and 3,515 CZK/ha in 2014, 215, and 2016, respectively).

In order to achieve comparable results, total costs were structured following the study of Poláčková et al. (2010) and broken out into variable and fixed costs in accordance with Kvapilík and Syrůček (2012). In the present study, variable costs included the costs of feed (self-produced and purchased), veterinary services, depreciation of cows, and intracompany costs. Fixed costs included wages, depreciation of fixed assets, energy costs, overheads, and other costs. Other costs involved purchased material and services, including insurance. The value of manure as a secondary output of animal production was deducted from total costs.

In addition, the participating farms were allocated into three groups according to the size of the herd $(<50,50$ to $100,>100$ cows) in order to evaluate economies of scale.

As it was impossible to acquire information about the depreciation rate for cows used in different herds, this was calculated as a fixed value for all operations on the basis of the weighted averages of the herd replacement rate, replacement heifer price, cow carcass weight, and price. The following model from Syrůček and Kvapilík (2015) was used:

$D C=(R c \times P h)-R c \times C W \times P c w c)$, where Dc is depreciation of cows per year, Rc is herd replacement rate, $\mathrm{Ph}$ is purchase price for a replacement heifer, CW is carcass weight, and Pcwc is price per kg of carcass weight (cows).

The profitability of suckler cow herds under the conditions of the CR was assessed using the following model calculating the profit per cow:

$\mathrm{PRsc}=(W C n \times W C w \times W C s p)+S s c-(\Sigma T C s c-F M s c)$

where PRsc is the profit per suckler cow and year, WCn is the number of calves weaned and sold per cow and year, WCw is the live weight of a calf sold, WCsp is the selling price per $\mathrm{kg}$ of calf live weight, Ssc is the subsidies per suckler cow and year, TCsc is the total cost per suckler cow and year, and FMsc is the value of manure per suckler cow and year.

The costs and profit were also determined per day on feed and per calf weaned.

Profitability is generally defined as the ratio of revenue to resources consumed. In this study, return on costs (ROC) was calculated as the quotient of the total profit divided by total costs:

$$
\mathrm{ROC}=\frac{\mathrm{PRsc}}{\left.\sum \mathrm{TCsc}-\text { FMsc }\right),} \times 100
$$

To assess the efficiency of the operation, a break-even point was defined and determined as the point at which costs and revenues are equal and the operation reaches zero profitability (Střeleček and Kollar, 2002). Following the methodology by Syrůček et al. (2017a), break-even points were estimated for the number of calves weaned, calving interval, selling price for $1 \mathrm{~kg}$ of calf's live weight, yearly feed costs, yearly total costs, and the level of yearly support payments. The break-even point indicates a minimum requirement for maintaining sustainability of the operation. Therefore, this also was calculated for the levels of annual profitability (ROC) at 5 and 10\%, which can be considered as optimum.

Also investigated was the question as to which of the input parameters had the greatest impact on the overall economic result. For this purpose, a sensitivity analysis as described by Syrůček et al. (2017a) was undertaken to examine potential changes in the model and their impacts on the different target variables. The impact of a $20 \%$ change in input parameters was examined, similarly as reported by Wolfová et al. (2004). The analysed parameters included price of calves, number of calves weaned, loss of calves, calving interval, herd turnover, subsidies, feed costs, labour costs, and overheads.

Where appropriate, the following currency exchange rates were used: 1 EUR $=27 \mathrm{CZK}$, $1 \mathrm{USD}=25 \mathrm{CZK}$. All calculations were made using Microsoft Excel 2016. 


\section{RESULTS AND DISCUSSION}

\section{Total costs and their variability}

Compared to other cattle operations, such as feedlot or dairy operations, suckler herds are characterized by less use of conserved forage and lower concentrates requirements, lower labour consumption, and less-demanding housing facility requirements (Kvapilík et al., 2006). Total yearly costs per cow have been estimated to be $40 \%$ lower in suckler herds compared to dairy operations (Kvapilík, 2016). In this study, total yearly costs per cow were 30,200, 30,525 and 31,024 CZK in 2014, 2015, and 2016, respectively (Tab. II), and were similar to those reported by Syrůček et al. (2017b). The total costs were on average 19\% higher than in Slovakia, for which data had been collected from 29 operations for the years 2008-2012 (Michaličková et al., 2015). The difference is mainly due to lower labour costs in Slovakia. In contrast, total yearly costs in Bavaria were markedly higher due to higher inputs and amounted to 48,000 CZK per cow in 2013 (Jahresbericht 2013, 2014).

Total yearly costs determined per weaned calf ranged between 34,000 and $36,000 \mathrm{CZK}$ in the present study. Due to a higher number of weaned calves in that year, they were lowest in 2016 in spite of the fact that the costs per cow were highest in that year. Total costs per feeding day ranged between 82.3 and $84.8 \mathrm{CZK}$. They were similar to those based on the results of 39 suckler herds from the CR in 2014 and 2015 (82.9 and 82.4 CZK per feeding day) (Peterková et al., 2017) and to those reported by the Institute of Agricultural Economics and Information (IAEI) in the CR, which came to 86.0 CZK per feeding day in 2015 (ÚZEI, 2017). Total costs per feeding day lower by 12 CZK had been determined earlier for the period 2008-2010 (Boudný a Janotová, 2012). That difference probably is due to annual inflation of $2 \%$ in the period 2008-2016 (Czech Statistical Office, 2017b). The total costs observed in this study were reduced by $8 \%$ to reflect the value of manure produced and averaged 28,088 CZK per cow and year.

In terms of cost structure, feed costs constituted the major cost item in every year. That is in agreement with multiple previous studies (e.g., Skunmun et al., 2002; Crosson et al., 2006). In this study, the feed costs accounted for $24 \%$ of the total costs, which proportion is similar to that reported by IAEI using data from the CR (ÚZEI, 2017) but lower than the $32 \%$ calculated by Michaličková et al. (2016) for suckler herds in Slovakia. The average depreciation of animals was determined in this study to be 2,262 CZK per year, which is approximately $200 \mathrm{CZK}$ higher than the result obtained on the basis of a model calculation using the herd turnover rate of $15 \%$ (Syrůček and Kvapilík, 2015). The sum of feed costs, wages, depreciation, and overheads accounted for $63-69 \%$ of total costs in the present study, which is somewhat lower than the $77 \%$ calculated in the report by IAEI (ÚZEI, 2017). Whereas a relatively low fluctuation of different cost items was observed among years, different suckler operations did vary considerably in the rate of fixed assets depreciation, overheads, and other costs, possibly due to the different methods of cost accounting used.

\section{Economies of scale}

The results given in Tab. III indicate that increasing herd size is associated with reduced costs per feeding day. A more detailed analysis indicated that total costs were reduced mainly

II: Variability of costs in suckler cow herds.

\begin{tabular}{|c|c|c|c|c|c|c|}
\hline \multirow{3}{*}{ Cost item } & \multicolumn{3}{|c|}{ in CZK per cow and year } & \multicolumn{3}{|c|}{ in CZK per feeding day } \\
\hline & 2014 & 2015 & 2016 & 2014 & 2015 & 2016 \\
\hline & Mean \pm SD & Mean \pm SD & Mean \pm SD & Mean \pm SD & Mean \pm SD & Mean \pm SD \\
\hline Own feeds & $6,584 \pm 1,622$ & $6,868 \pm 3,579$ & $7,048 \pm 1,174$ & $18.0 \pm 4.4$ & $18.8 \pm 9.9$ & $19.3 \pm 3.2$ \\
\hline Purchased feeds & $587 \pm 600$ & $641 \pm 664$ & $585 \pm 547$ & $1.6 \pm 1.7$ & $1.8 \pm 1.8$ & $1.6 \pm 1.5$ \\
\hline Total feed costs & $7,171 \pm 2,408$ & $7,510 \pm 4,085$ & $7,633 \pm 4,291$ & $19.6 \pm 6.6$ & $20.6 \pm 11.2$ & $20.9 \pm 3.2$ \\
\hline Labour costs & $4,664 \pm 2,553$ & $5,111 \pm 2,739$ & $5,327 \pm 2,839$ & $12.8 \pm 7.0$ & $14 \pm 7.1$ & $14.6 \pm 7.8$ \\
\hline Veterinary services & $526 \pm 397$ & $455 \pm 370$ & $477 \pm 442$ & $1.4 \pm 1.1$ & $1.2 \pm 1.0$ & $1.3 \pm 1.2$ \\
\hline Depreciation of fixed assets & $1,551 \pm 2,229$ & $1,981 \pm 2,607$ & $2,611 \pm 3,686$ & $4.2 \pm 5.0$ & $5.4 \pm 7.2$ & $7.1 \pm 10.3$ \\
\hline Depreciation of animals & 2,311 & 2,382 & 2,092 & 6.3 & 6.5 & 5.7 \\
\hline Energy and fuels & $1,447 \pm 2,461$ & $1,219 \pm 1,586$ & $1,280 \pm 1,894$ & $4.0 \pm 6.7$ & $3.3 \pm 3.9$ & $3.5 \pm 5.2$ \\
\hline Overheads & $3,311 \pm 4,445$ & $3,967 \pm 2,008$ & $2,840 \pm 3,056$ & $9.1 \pm 12.2$ & $10.9 \pm 5.4$ & $7.8 \pm 8.4$ \\
\hline Intra-company costs & $3,921 \pm 2,688$ & $3,888 \pm 4,075$ & $4,151 \pm 3,864$ & $10.7 \pm 7.4$ & $10.7 \pm 11.2$ & $11.3 \pm 9.4$ \\
\hline Other costs & $5,299 \pm 3,730$ & $4,013 \pm 3,650$ & $4,614 \pm 3,481$ & $14.5 \pm 7.5$ & $11 \pm 10.2$ & $12.6 \pm 9.5$ \\
\hline Total costs & 30,200 & 30,525 & 31,024 & 82.7 & 83.6 & 84.8 \\
\hline Manure value & $2,813 \pm 2,212$ & $2,216 \pm 396$ & $2,458 \pm 469$ & $7.7 \pm 6.1$ & $6.1 \pm 1.1$ & $6.7 \pm 1.3$ \\
\hline $\begin{array}{l}\text { Total costs reduced by } \\
\text { manure }\end{array}$ & 27,388 & 28,309 & 28,567 & 75.0 & 77.6 & 78.1 \\
\hline
\end{tabular}

$\mathrm{SD}=$ standard deviation. 
due to decreasing fixed costs, and especially labour costs, overheads, and depreciation of fixed assets. In agreement with the study by Střeleček and Kollar (2002), it was determined that especially labour costs as the main item of fixed costs were reduced with increasing herd size. Similarly, the highest labour productivity was identified in large-sized farms in a study based on the accounting data of 926 Czech farms (Novotná and Volek, 2016). Increasing suckler herd size might therefore be of importance for achieving sufficient income and profitability (Gajos and Dymnicki, 2012). Productivity can be improved by greater scale. Moreover, an increase in farm size may also be associated with new opportunities to capitalize on new techniques, technologies, and practises that can also improve productivity (Veysset et al., 2015).

\section{Calculation of profitability}

Although the highest average price per $1 \mathrm{~kg}$ live weight of calf sold was recorded in 2015, the revenues from calf sales per cow were highest in 2016 (Tab. IV). That was due mainly to higher numbers of calves born, weaned, and sold per 100 cows in that year. When subsidies were excluded from the calculation, profitability was negative in the range of -42 to $-46 \%$. Negative profitability

III: Average costs perfeeding day during 2014-2016, by herd size.

\begin{tabular}{llll}
\hline Cost item & \multicolumn{1}{l}{ Costs in CZK per feeding day } & \\
\hline Number of cows in herd & $<50$ & 50 to 100 & $>100$ \\
Number of herds & 17 & 16 & 28 \\
\hline Own feed & 18.24 & 17.74 & 19.47 \\
\hline Purchased feed & 1.56 & 1.84 & 1.66 \\
\hline Total feed costs & 19.80 & 19.58 & 21.13 \\
\hline Labour costs & 15.51 & 13.78 & 12.94 \\
\hline Veterinary services & 1.51 & 1.69 & 0.93 \\
\hline Depreciation of fixed assets & 7.79 & 5.98 & 3.81 \\
\hline Depreciation of animals & 6.21 & 6.21 & 6.21 \\
\hline Energy and fuels & 5.58 & 4.33 & 1.93 \\
\hline Overheads & 10.15 & 9.50 & 8.79 \\
\hline Intra-company costs & 11.57 & 10.91 & 10.40 \\
\hline Other costs & 14.95 & 13.06 & 11.11 \\
Total variable costs & 39.10 & 38.39 & 38.67 \\
\hline Total fixed costs & 54.00 & 46.66 & 38.57 \\
\hline Total costs & 93.10 & 85.05 & 77.24 \\
\hline
\end{tabular}

IV: Calculation of sucklerherd profitability

\begin{tabular}{lllll}
\hline \multicolumn{1}{c}{ Items } & Unit & $\mathbf{2 0 1 4}$ & $\mathbf{2 0 1 5}$ & $\mathbf{2 0 1 6}$ \\
\hline Average weight of calf sold & $\mathrm{kg}$ & 273 & 280 & 282 \\
\hline Average price for calf sold per kg of live weight & CZK & 64.78 & 66.51 & 64.96 \\
\hline Revenue from sale of calf & CZK & 17,664 & 18,651 & 18,332 \\
Revenues from sale of calves per suckler cow & CZK & 14,829 & 16,279 & 16,627 \\
\hline Total annual costs after reduction & CZK & 27,388 & 28,309 & 28,567 \\
\hline Profit without subsidies per suckler cow & CZK & $-12,558$ & $-12,030$ & $-11,940$ \\
\hline Profit without subsidies per feeding day & CZK & -34.41 & -32.96 & -32.62 \\
\hline Profit without subsidies per weaned calf & CZK & $-14,958$ & $-13,783$ & $-13,164$ \\
\hline Profitability (ROC) without subsidies & \% & -45.85 & -42.49 & -41.80 \\
\hline Annual amount of subsidies per suckler cow & CZK & 14,826 & 14,483 & 13,732 \\
\hline Profit including subsidies per suckler cow & CZK & 2,268 & 2,453 & 1,792 \\
\hline Profit including subsidies per feeding day & CZK & 6.21 & 6.72 & 4.90 \\
\hline Profit including subsidies per weaned calf & CZK & 2,702 & 2,811 & 1,976 \\
\hline Profitability (ROC) including subsidies & \% & 8.28 & 8.67 & 6.27 \\
\hline
\end{tabular}

ROC $=$ return on costs. 
values determined in suckler cow herds without subsidies under the conditions of the CR had been reported in previous studies as $-29 \%$ (Wolfová et al., 2004), -23\% (Wolfová et al., 2006), -54\% (Boudný and Janotová, 2012), and -46\% (Syrůček et al., 2017b). Similarly, a loss of $-42 \%$ had been determined for cow-calf operations in Slovakia (Michaličková et al., 2015).

In the present study, subsidies contributed $47 \%$ to the total revenue of suckler herds, whereas a higher proportion of $62 \%$ had been reported by Boudný and Janotová (2012) in a model calculation with all eligible subsidies included. In agreement with our results, Gajos and Dymnicki (2012) had estimated the proportion of support payments in the total revenue of beef production systems in Poland to be between 44 and $48 \%$, whereas a somewhat lower contribution of subsidies (32\%) was determined in Slovakia (Michaličková et al., 2015).

Profit of 6,210 CZK per cow per year while including yearly subsidies of 12,447 CZK per suckler cow was achieved in Germany in 2012 (Münchhausen, 2014). In the present study, the average profits including subsidies were 2,702, 2,811, and 1,976 CZK per

V: Break-even analysis.

\begin{tabular}{|c|c|c|c|c|c|c|c|}
\hline \multirow[b]{2}{*}{ Item } & \multirow[b]{2}{*}{ Unit } & \multicolumn{2}{|c|}{2014} & \multicolumn{2}{|c|}{2015} & \multicolumn{2}{|c|}{2016} \\
\hline & & $\begin{array}{c}\text { Break-even } \\
\text { point }\end{array}$ & Difference $^{1)}$ & $\begin{array}{c}\text { Break-even } \\
\text { point }\end{array}$ & Difference ${ }^{1)}$ & $\begin{array}{c}\text { Break-even } \\
\text { point }\end{array}$ & 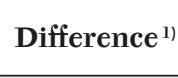 \\
\hline Weaned calves & n/100 cows & 71 & -13 & 74 & -13 & 81 & -10 \\
\hline Calving interval & days & 485 & +73 & 468 & +68 & 440 & +42 \\
\hline $\begin{array}{l}\text { Price for calf } \\
\text { sold }\end{array}$ & $\begin{array}{l}\text { CZK/ kg live } \\
\text { weight }\end{array}$ & 54.88 & -9.9 & 56.49 & -10.02 & 57.96 & -7.00 \\
\hline Feed costs & CZK/cow/year & 9,439 & $+2,268$ & 9,963 & $+2,453$ & 9,425 & $+1,792$ \\
\hline $\begin{array}{l}\text { Total annual } \\
\text { costs }\end{array}$ & CZK/cow/year & 32,469 & $+2,268$ & 32,978 & $+2,453$ & 32,816 & $+1,792$ \\
\hline Subsidies & CZK/cow/year & 12,558 & $-2,268$ & 12,030 & $-2,453$ & 11,940 & $-1,792$ \\
\hline
\end{tabular}

1) Difference from the value obtained in a given year

VI: Break-even point at $5 \%$ and $10 \%$ profitability (ROC).

\begin{tabular}{|c|c|c|c|c|c|c|c|}
\hline \multirow{2}{*}{ Item } & \multirow{2}{*}{ Unit } & \multicolumn{2}{|c|}{2014} & \multicolumn{2}{|c|}{2015} & \multicolumn{2}{|c|}{2016} \\
\hline & & $5 \%$ & $10 \%$ & $5 \%$ & $10 \%$ & $5 \%$ & $10 \%$ \\
\hline Weaned calves & n/100 cows & 79 & 87 & 82 & 89 & 89 & 97 \\
\hline Calving interval & days & 437 & 398 & 425 & 389 & 402 & 369 \\
\hline $\begin{array}{l}\text { Price for calf } \\
\text { sold }\end{array}$ & $\begin{array}{l}\text { CZK/ kg live } \\
\text { weight }\end{array}$ & 60.86 & 66.84 & 62.27 & 68.05 & 63,54 & 69.12 \\
\hline Feed costs & CZK/cow/year & 8,027 & 6,743 & 8,498 & 7,166 & 7,979 & 6,665 \\
\hline $\begin{array}{l}\text { Total annual } \\
\text { costs }\end{array}$ & CZK/cow/year & 31,056 & 29,773 & 31,513 & 30,182 & 31,371 & 30,056 \\
\hline Subsidies & CZK/cow/year & 13,928 & 15,297 & 13,445 & 14,861 & 13,368 & 14,796 \\
\hline
\end{tabular}

ROC $=$ return on costs.

VII: Sensitivity analysis of production and economic parameters.

\begin{tabular}{|c|c|c|c|c|c|c|c|c|}
\hline \multirow[t]{3}{*}{ Item } & \multicolumn{6}{|c|}{ Profit including subsidies per cow and year (CZK) } & \multirow{2}{*}{\multicolumn{2}{|c|}{$\begin{array}{l}\text { Average change in } \\
\text { annual profit (CZK) }\end{array}$}} \\
\hline & \multicolumn{2}{|c|}{2014} & \multicolumn{2}{|c|}{2015} & \multicolumn{2}{|c|}{2016} & & \\
\hline & $+20 \%$ & $-20 \%$ & $+20 \%$ & $-20 \%$ & $+20 \%$ & $-20 \%$ & $+20 \%$ & $-20 \%$ \\
\hline Price of calves & $+5,234$ & -698 & $+5,709$ & -802 & $+5,117$ & $-1,533$ & $+3,114$ & $-3,114$ \\
\hline No. of calves weaned & $+5,174$ & -638 & $+5,612$ & -705 & $+5,028$ & $-1,443$ & $+3,036$ & $-3,036$ \\
\hline Loss of calves & $+2,095$ & $+2,442$ & $+2,286$ & $+2,620$ & $+1,711$ & $+1,873$ & -137 & +137 \\
\hline Calving interval & -203 & $+5,976$ & -260 & $+6,523$ & -979 & $+5,949$ & $-2,582$ & $+3,873$ \\
\hline Herd turnover & $+1,806$ & $+2,731$ & $+1,977$ & $+2,930$ & $+1,374$ & $+2,210$ & -406 & +406 \\
\hline Subsidies & $+5,234$ & -697 & $+5,350$ & -443 & $+4,538$ & -954 & $+2,788$ & $-2,788$ \\
\hline Feed costs & +834 & $+3,702$ & +952 & $+3,955$ & +265 & $+3,319$ & $-1,513$ & $+1,513$ \\
\hline Labour costs & $+1,335$ & $+3,201$ & $+1,431$ & $+3,476$ & +727 & $+2,857$ & $-1,037$ & $+1,037$ \\
\hline Overheads & $+1,606$ & $+2,931$ & $+1,660$ & $+3,247$ & $+1,224$ & $+2,360$ & -676 & +676 \\
\hline
\end{tabular}


cow in 2014, 2015, and 2016, respectively, with the profitability ranging from 6.3 to $8.7 \%$. A lower profitability reached in 2016 can be explained by a lower rate of subsidies, and particularly by a lower VCS targeted to beef calves. Syrůček et al. (2017b) had reported a lower profitability of suckler herds in the CR based on data from 2013 $(2.2 \%)$ as result of lower support payments. Conversely, higher profitability of $13.1 \%$ had been determined in the model calculation by Boudný and Janotová (2012). Profit and profitability in suckler cow herds had been determined for Mecklenburg-West Pomerania (Germany) in 2014 and 2015 to be 2,375 CZK/cow and $5.7 \%$, respectively (Weber and Kvapilík, 2016). Compared to the present study, lower costs and higher revenues from sale of calves resulted in a yearly profit of $8,135 \mathrm{CZK} / \mathrm{cow}$ in a cow-calf operation in Northern Utah in the USA (Holmgren and Feuz, 2015).

\section{Break-even analysis}

The operations included in this study were on average profitable, and therefore the break-even points at $0 \%$ profitability for various parameters are lower than those actually achieved (Tab. V). The break-even points for the number of weaned calves were 71,74 , and 81 calves per 100 cows in 2014, 2015, and 2016, respectively, and were slightly lower than those reported by Syrůček et al. (2017b). This means that under model conditions in a particular year zero profitability of the suckler herd is reached when at least such a number of calves per 100 cows is weaned and sold. The break-even point for the calving interval was calculated as 464 days, 64 days longer than the actual average calving interval observed. In order to achieve 5 or $10 \%$ levels of profitability, the parameters would have to be improved over the calculated break-even points as shown in Tab. VI.

\section{Sensitivity analysis}

Tab. VII shows how a $\pm 20 \%$ change in production and economic parameters altered profitability per cow. Model calculations indicated that profitability was mainly influenced by the number of calves weaned and sold, price of calves, calving interval, and support payments. A $20 \%$ reduction in the selling price for calves or a $20 \%$ decrease in the number of calves weaned would put an operation in economic loss. Conversely, a $20 \%$ selling price increase would improve the overall profitability by $11.3 \%$. The price of calves has been reported previously as the major factor influencing suckler cow herd profitability (Wolfová et al., 2004). In that study, a $20 \%$ price increase had improved profitability by $8.2 \%$. Reproduction is another important factor with a significant effect on beef herd profitability (Wolfová et al., 2005). The sensitivity analysis in this study identified the number of weaned calves per cow as the second most important parameter for herd profitability. Feed costs and price were the most sensitive cost items in this study. Wolfová et al. (2004) had determined that $20 \%$ higher feed costs resulted in $4.4 \%$ lower profitability, which finding was similar to that of our study. Calf losses, presumably due to their low absolute values, and culling rates were identified by the sensitivity analysis as less important. Culling rates are associated with cow depreciation and their lower importance can be explained by the fact that higher culling rates would increase the cost of heifers but would at the same time increase the revenues from sale of cows.

\section{CONCLUSIONS}

Suckler cow enterprises comprise an important segment of Czech agriculture. As the net production of beef in the EU is lower than its consumption, the global consumption of beef is forecast to rise substantially, and permanent grassland areas are still underutilized in the CR, further increase of suckler cow numbers can be expected in the CR. Suckler cow herds are also important for the non-production functions they serve, such as maintaining grazed areas or providing employment in rural areas. Achieving a reasonable level of profitability is nevertheless essential to maintaining and further developing suckler cow enterprises.

The results of the present study indicate that suckler cow enterprises are profitable only when subsidies are included. Average profitability of 8.3, 8.7 and $6.3 \%$ was determined for 2014, 2015, and 2016. When subsidies were excluded, negative profitability ranging from -42 to $-46 \%$ was observed. It is evident, therefore, that in addition to improving production characteristics, it is a necessity to utilize all types of payment supports available to secure sufficient farm income. Detailed cost analysis demonstrated a possibility to take advantage of economies of scale, and the high proportion of fixed costs amounts to an average $54 \%$ of total costs. The factors most sensitive to change are the selling price of calves, number of calves weaned, subsidies, and calving interval.

\section{Acknowledgments}

This research was supported by project of the Ministry of Agriculture of the Czech Republic [MZE-RO0718], project of the National Agency for Agricultural Research of the Czech Republic [NAZV QJ1510191], and by the Ministry of Education, Youth and Sports of the Czech Republic ["S" grant]. 


\section{REFERENCES}

BERGER, A. 2014. Cow Depreciation - A Hidden Significant Non-Cash Expense for Cow-Calf Producers. [Online]. University of Nebraska-Lincoln. Available at: http://newsroom.unl.edu/announce/beef/3616/20970 [Accessed: 2017, September 5].

BOUDNÝ, J. and JANOTOVÁ, B. 2012. Economics of breeding beef cattle during 2008-2010 [in Czech: Ekonomika chovu masného skotu v letech 2008-2010]. Náš chov, 72(5): 36-39.

CROSSON, P., O'KIELY, P., O'MARA, F. P. and WALLACE, M. 2006. The development of a mathematical model to investigate Irish beef production systems. Agr. Syst., 89(2-3): 349-370.

CZECH STATISTICAL OFFICE. 2017a. Livestock Survey [in Czech: Soupis hospodářských zvířat]. [Online]. Czech Statistical Office. Available at: https://www.czso.cz/csu/czso/soupis-hospodarskych-zvirat-k-1-4-2017 [Accessed: 2017, September 12].

CZECH STATISTICAL OFFICE. 2017b. Key Macroeconomic Indicators [in Czech: Hlavní makroekonomické ukazatele]. [Online]. Czech Statistical Office. Available at: https://www.czso.cz/csu/czso/hmu_cr [Accessed: 2017, September 12].

DAVIES, B. L., ALFORD, A. R. and GRIFFITH, G. R. 2009. Economic effects of alternate growth path, time of calving and breed type combinations across southern Australian beef cattle environments: feedlot finishing at the New South Wales experimental site. Anim. Prod. Sci., 49(5-6): 535-541.

EUROSTAT. 2017. Number of cattle. Eurostat. [Online]. Available at: http://ec.europa.eu/eurostat/web/ agriculture/data/main-tables [Accessed: 2017, September 12].

GAJOS, E. and DYMNICKI, E. 2012. Beef production based on a suckling system as an alternative to milk production at the example of Polish Red cattle. Anim. Sci. Pap. Rep., 30(4): 353-361.

HOLMGREN, L. and FEUZ, D. 2015. Costs and Returns for a 200 Cow, Cow-Calf Operation, Northern Utah. [Online]. Utah State University. Available at: http://digitalcommons.usu.edu/cgi/viewcontent. cgi?article=1716\&context=extension_curall[Accessed: 2017, February 28].

JAHRESBERICHT 2013. 2014. Annual Report 2013 [in German: Jahresbericht 2013]. [Online]. Bayerische Landesanstalt für Landwirtschaft Institut für Betriebswirtschaft und Agrarstruktur. Available at: https:// www.lfl.bayern.de/mam/cms07/iba/dateien/lfl-iba_jahresbericht-2013.pdf [Accessed: 2017, March 15].

JONES, J. V. H. 2007. The use of relevant cost analysis to assess production viability following the decoupling of support payments in England. International Farm Management Association, 16(3): 412-421.

KVAPILİK, J. 2016. Comparison of economic indicators of breeding dairy cows and suckler cows [in Czech: Porovnání ekonomických ukazatelů chovu dojených a nedojených krav]. Náš chov, 76(6): 25-29.

KVAPILÍK, J. and SYRU゚ČEK, J. 2012. Calculation of gross margin and the full cost [in Czech: Kalkulace př́spěvku na úhradu a úplných nákladů]. Náš chov, 72(3): 22-26.

KVAPILÍK, J. and ZAHRÁDKOVÁ, R. 2007. Selected indicators of suckler cow herds [in Czech: Vybrané ukazatele chovu krav bez tržní produkce mléka]. Náś chov, 67(10): 23-27.

KVAPILÍK, J., PYTLOUN, J., ZAHRÁDKOVÁ, R. and MALÁT, K. 2006. Breeding of suckler cows, methodical guide for advisers [in Czech: Chov krav bez tržní produkce mléka, metodická př́ručka pro poradce]. Prague: Institute of Animal Science.

LOSOSOVÁ, J., SVOBODA, J. and ZDENĚK, R. 2016. Comparison of Operational Subsidies on Less Favoured Areas in EU Countries. Acta Universitatis Agriculturae et Silviculturae Mendelianae Brunensis, 64(3): 979-992.

MICHALIČKOVÁ, M., KRUPOVÁ, Z. and KRUPA, E. 2015. Economic evaluation of cow-calf herds. I. Calculation methods. Anim. Sci.Pap. Rep., 33(3): 257-266.

MICHALIČKOVÁ, M., SYRU゚ČEK, J., KRUPOVÁ, Z. and KRUPA. E. 2016. Economy of suckler cow herds [in Slovak: Ekonomika chovu kráv bez trhovej produkcie mlieka]. Nášchov, 76(4): 44-47.

MINISTRY OF AGRICULTURE. 2017. Subsidies [in Czech: Dotace]. [Online]. Ministry of Agriculture. Available at: http://eagri.cz/public/web/mze/dotace [Accessed: 2017, February 7].

MÜNCHHAUSEN, S. 2014. Efficiency of beef cattle farming and potential for influencing quality [in German: Wirtschaftlichkeit der Fleischrinderhaltung und Einflussmö glichkeiten auf die Qualität]. Eberswalde, Germany: Hochschule für nachhaltige Entwicklung Eberswalde (FH).

NAYIGIHUGU, V., SCHLEICHER, A. D., KOCH, D. W., HELD, L. J., FLAKE, J. W., and HESS, B. W. 2007. Beef cattle production, nutritional quality, and economics of windrowed forage vs. baled hay during winter. Agron. J., 99(4): 944-951.

NOVOTNÁ, M. and VOLEK, T. 2016. The Significance of Farm Size in the Evaluation of Labour Productivity in Agriculture. Acta Universitatis Agriculturae et Silviculturae Mendelianae Brunensis, 64(1): 333-340.

PETERKOVÁ, J., RÁDLOVÁ, L., and BOUDNÝ, J. 2017. Economy of beef cattle breeding in ecological and conventional mode [in Czech: Ekonomika chovu masného skotu v ekologickém a konvenčním režimu]. Náśchov, 77 (3): 39-43.

POLÁČKOVÁ, J., BOUDNÝ, J., JANOTOVÁ, B. and NOVÁK, J. 2010. Methodology for calculating costs and revenues in agriculture [in Czech: Metodika kalkulací nákladů a výnosů v zemědělství]. Prague: Institute of Agricultural Economics and Information. 
SACHER, M. and DIENER, K. 2004. Profitability of suckler cows in 2002/03 [in German: Wirtschaftlichkeitsbericht Mutterkühe 2002/03]. [Online]. Sächsische Landesanstalt für Landwirtschaft. Available at: https:// publikationen.sachsen.de/bdb/artikel/15274. [Accessed: 2017, February 9].

SKUNMUN, P., CHANTALAKHANA, C., PUNGCHAI, R., POONDUSIT, T. and PRUESASRI, P. 2012. Comparative feeding of male dairy, beef cattle and swamp buffalo I. Economics of beef production. Asian Austral. J. Anim., 15(6): 878-883.

STŘELEČEK, F. and KOLLAR, P. 2002. Searching the proportional level of operating costs - specification of the minimum volume of production. Agricultural Economics - Czech, 48(3): 106-116.

SYRŮČEK, J. and KVAPILÍK, J. 2015. Depreciation of suckler cows [in Czech: Odpisy krav bez tržní produkce mléka]. Nášchov, 75(9): 92-94.

SYRŮČEK, J., KRPÁLKOVÁ, L., KVAPILÍK, J., and VACEK, M. 2017a. Calculation of economic indicators in cattle breeding [in Czech: Kalkulace ekonomických ukazatelu v chovu skotu]. Certified methodology. Prague: Institute of Animal Science.

SYRU゚ČEK, J., KVAPILÍK, J., BARTOŇ, L., VACEK, M., and STÁDNÍK, L. 2017b. Economic efficiency of suckler cow herds in the Czech Republic. Agr. Econ.-Czech, 63(1): 34-43.

TAYLOR, D. B., MOON, R. D., and MARK, D. R. 2012. Economic Impact of Stable Flies (Diptera: Muscidae) on Dairy and Beef Cattle Production. J. Med. Entomol., 49(1): 198-209.

ÚZEI. 2015. Costs of Agricultural Products [in Czech: Nákladovost zemédèlských výrobků]. [Online]. Institute of Agricultural Economics and Information. Available at: http://www.uzei.cz/data/usr_001_cz_ soubory/2015.pdf [Accessed: 2017, September, 12].

VEYSSET, P., LHERM, M., ROULENC, M., TROQUIER, C. and BEBIN, D. 2015. Productivity and technical efficiency of suckler beef production systems: trends for the period 1990 to 2012. Animal, 9(12): 2050-2059.

WEBER, S. and KVAPILIIK, J. 2016. Indicators of suckler cows in Mecklenburg-Vorpommern [in Czech: Ukazatele chovu krav bez TPM ve spolkové zemi Mecklenburg-Vorpommern]. Beef cattle magazine, 3: 30-32.

WOLFOVÁ, M., WOLF, J., ZAHRÁDKOVÁ, R., PǨIBYL, J., DANO, J. and KICA, J. 2004. Main sources of the economic efficiency of beef cattle production systems. Czech Journal of Animal Science, 49(8): 357-372.

WOLFOVÁ, M., PŘIBYL, J., WOLF, J. and ZAHRÁDKOVÁ, R. 2006. Effect of subsidy regimes on economic values of functional traits in beef cattle breeding. J. Anim. Breed. Genet.,123: 97-104.

WOLFOVÁ, M., WOLF, J., ZAHRÁDKOVÁ, R., PŘIBYL, J., DANO, J., KRUPA, E. and KICA, J. 2015. Breeding objectives for beef cattle used in different production systems: 2. Model application to production systems with the Charolais breed. Livest. Prod. Sci., 95(3): 217-230.

Jan Syrůček: syrucek.jan@vuzv.cz Luděk Bartoň: barton.ludek@vuzv.cz Jindřich Kvapilík: kvapilik.jindrich@vuzv.cz Mojmír Vacek: vacekm@af.czu.cz Luděk Stádník: stadnik@af.czu.cz 